[This is the post-print version of a short article for the Special Issue: ICT Research and Disciplinary Boundaries: Is "Internet Research" a Virtual Field, a Proto-Discipline, or Something Else?"(Guest Editor: Nancy K. Baym), Information Society, Volume 21, No. 4, 2005, pp. 317-320. See: http://www.indiana.edu/ tisj/ ]

\title{
ICT Research, the New Economy, and the Evolving Discipline of Economics: Back to the Future?
}

\author{
Hans-Jürgen Engelbrecht, \\ Professor of Economics, \\ Department of Applied and International Economics, \\ Massey University, \\ Palmerston North, \\ NEW ZEALAND
}

\begin{abstract}
Economics-related ICT research has moved from the fringes of the discipline to penetrate all of its branches. It is, therefore, not a separate economics sub-discipline. It is also unlikely to become part of an 'ICT or Internet Research' proto-discipline. Instead, it should be seen as only one part of a bigger agenda toward a proper ‘information and knowledge economics' and possibly a future proto-discipline of a 'unified theory of information and knowledge' or a meta-discipline of information sciences.
\end{abstract}

\section{KEYWORDS}

Information economy, knowledge(-based) economy, New Economy, ICT, Internet, general purpose technology, unified theory of information and knowledge. 
This paper is written by an economist and deals with the position of Information and Communication Technologies (ICT) research, including Internet-related research, in economics. It also comments on the changing nature of economics itself, which has major implications for the former. In order to provide the background for the arguments stated below, it is useful to briefly recall some aspects of the history of information and knowledge(-based) economy research. ${ }^{1}$

\section{FROM THE PIONEERS...}

The analysis of information/knowledge economy-related issues, including those concerning the impact of ICT, was initially confined to the fringes of economics but is now firmly established in the mainstream economics literature. The early pioneering analyses of Machlup (1962), Bell (1973) and Porat and Rubin (1977) adopted a wider perspective on the information economy than the technology (i.e. ICT) information economy focussed on in recent decades by the OECD and most economists interested in these issues. The pioneers saw 'information machines' as only a small component compared to the total of all activities concerned with the generation, processing and distribution of information/knowledge in the economy, and society in general.

Analyses building on the contribution of the pioneers that used the wider perspective encountered resistance in the economics profession and had to be published either in journals of other disciplines or in non-mainstream economics journals. To give but one example from personal experience, early papers trying to assess the value of information services as a factor of production, i.e. using an established economic methodology, were published in this journal (see, e.g., Hayes and Erickson, 1982). 
One of my own contributions to this line of research (Engelbrecht, 1988) was at first rejected by a mainstream economics journal as 'too specialised' to be of interest to a general economics readership. Only when the new information economy perspective supplemented more closely not only existing economic methodology but also topics of mainstream economics discourse were economics journals increasingly interested in papers employing information inputs into production function analysis and related analyses like growth accounting. ${ }^{2}$

...TO THE MAINSTREAM...

How times have changed. With the narrowing of the scope of analysis from the wider information economy to the information technology economy, and further to the Internet economy, ${ }^{3}$ and with the performance of the US economy since the second half of the 1990s demanding explanation, ICT research has moved from the fringes to the main stage in economics. ${ }^{4}$ From a disciplinary perspective one may ask whether this indicates the emergence of a new 'ICT or Internet economics' sub-discipline or whether it is a feature of the changing nature of economics in general. Although there is evidence for both, my bet is on the latter.

To explore this issue (in an admittedly simple fashion), I used the Internet as a research tool to assertion the spread of Internet-related research in economics in the post-dotcom bubble era. A quick check of EconLit, the American Economics Association's electronic bibliography of economics literature throughout the world, revealed that Internet Research is being conducted in many of the sub-disciplines of economics. I first searched for journal articles published between October 2001 and 
October 2003 that included the word 'Internet' in the title (the search was conducted on December 22, 2003). EconLit came up with 156 entries across a wide variety of economics and economics-related journals. When the search included the abstract as well, the number of entries rose to 279. However, this does not capture, for example, any of the publications on ICT and economic growth that do not specifically refer to the Internet. Neither does it include any publications in 'The Information Society', which is not included in EconLit.

A small selection of the journals that published Internet-related research includes:

American Economic Review, Journal of Political Economy, Economic Inquiry, Economics Letters, RAND Journal of Economics, Journal of Regulatory Economics, Research Policy, Journal of Finance, Monthly Labor Review, Journal of Economic Psychology, Urban Studies, Review of Agricultural Economics, Journal of Accounting and Economics, Journal of Economic Issues, as well as more immediately obvious journals like Information Economics and Policy, Netnomics, and Telecommunications Policy.

Contemplating the many topics covered in these publications, one quickly realises that there is no well-demarcated economics specialization or sub-discipline of ICT or Internet Economics that encompasses all of the Internet-related topics addressed by economists. ${ }^{5}$ For sure, there is 'information economics', but this branch of economics is usually quite narrow in its focus (see Quah’s comments below) and not particularly ICT oriented, although Stiglitz (2002) sees it as a fundamental change in the prevailing economics paradigm. Then there is a fledgling 'Internet Economics' as defined by, for example, McKnight and Bailey (1997, p. 3) as the "study of the 
market for Internet services”, and its overlap with telecommunications and regulatory economics. This, too, is a rather narrow field.

Instead, ICT- and Internet-related research seems to have penetrated most branches of economics, and is likely to continue to do so in future. The Internet has the ability to generate new data sources, thereby enabling new lines of research. This is not only due to the increased ability to link and match more and more of the existing databases, but it is also due to the potential to collect new types of data. To the extent that this will happen, the importance of the Internet as a research tool and research object will further increase in many of the existing branches of economics.

That should make it more difficult to establish a multi-disciplinary based protodiscipline of ICT or Internet Research that encompasses all economics-related Internet research because most sub-disciplines of economics would have to contribute to it. This does not imply that economics-related Internet research cannot benefit from other disciplines, or that it should not be part of increased interdisciplinary research efforts. First, in the recent past economics in general has arguably taken more note of other disciplines to the extent that some observes wonder whether soon it may be hard to disentangle economics from other social sciences (Economist, 1998); secondly, there seems much room to increase the presents of economists in inter-disciplinary associations like the a.o.i.r.

...TO THE NEW ECONOMY ... 
One label that can be attached to a broad variety of economics research on the impact of the Internet and other new information technologies is that of the (since the dotcom crash sobered up) 'New Economy' (NE). In fact, the emergence of the Internet as a widespread means of communication, production and commerce has elevated important parts of the information and knowledge(-based) economy to a new level, i.e. that of the NE.

The explosion in the volume of digital goods and services made possible by the Internet has taken on a dominant, if not the defining role, in the NE. For example, for Quah (2003) the NE is an economy in which digital goods are major determinants of aggregate economic outcomes, i.e. of innovation, production and consumption. ${ }^{6} \mathrm{He}$ includes in digital goods ideas and knowledge, computer software, visual images, music, databases, video games, blueprints, recipes, DNA sequences, codified messages, etc. Quah's NE definition includes both the supply side (i.e. the role of knowledge in economic growth, the knowledge-based economy) and the demand side (i.e. the economics of digital consumer goods). He does not include the traditional economics of information and uncertainty concerned with risk and agency, moral hazard and adverse selection, signalling, and strategic behavior under asymmetric and imperfect information (ibid., p. 295/6).

Quah's definition should, of course, not be taken as the final word on the issue. There are other related and partly overlapping attempts to come to terms with the economic impacts of ICT. Foray (2004), for example, tries to define the scope of a new 'economics of knowledge' in which ICT has a prominent place. Unlike Quah, he neglects e-commerce issues but focuses instead on ICT' role in the knowledge 
creation, distribution and absorption processes at the heart of the knowledge-based economy. It is that role that might distinguish ICT from earlier 'general purpose technologies' like electricity ${ }^{7}$, i.e. it is what might make ICT 'special' compared to other technologies. Within economics, this point is still being debated ${ }^{8}$, as is the question of what to include in an economics of the knowledge-based economy and NE. I am critical of both Quah’s and Foray's rather narrow definitions. ${ }^{9}$

During the dotcom bubble era in the US and elsewhere it was fashionable in some quarters to believe in the suspension of the 'laws of economics'. ${ }^{10}$ The majority of observers would agree that since the bursting of the dotcom bubble, the conventional laws have come back with a vengeance, but, as the contributions to the New Economy Handbook (Jones, 2003) and to Pohjola (2002) attest, fundamental changes are nevertheless afoot in mainstream economics and related disciplines concerned with the impact of the Internet and other ICT. Whether 'special' or not, these technologies will, over time, change the emphasis of, and methodologies used in, economics, but it is unlikely that the majority of researchers examining these issues will stop thinking of themselves as economists.

\section{...AND BACK?}

If one wishes to contemplate whether economics-related ICT research is likely to become part of a developing new proto-discipline, one also has to consider other aspects of the changing nature of economics beside those usually captured by the terms knowledge-based economy and NE. They provide additional, albeit more speculative, support for the view that an ICT or Internet Research proto-discipline 
would probably be too narrow in scope, at least from the vantage point of a 'new economics'.

Outside the current mainstream are signs that economics is changing into a more evolutionary, cognitive, institutional and computational economics. Combined with changes in mainstream economics, this might evolve into a new synthesis or paradigm more in tune with the realities of an information/knowledge-based (world) economy in which ICT are an important, but not the only important, feature (Engelbrecht, 1998, 2003). Of course, the nature and boundaries of such a truly 'information and knowledge economics' have yet to be established. Some pertinent pointers are indicated by, for example, the contributions of Potts and Mirowski. Potts (2000) suggests the unification of all heterodox economics by proposing an evolutionary microeconomics based on the idea of non-integral space, i.e. the fact that not everything is connected to everything else. Connections are interpreted as information. Changing connections are the dynamics that change the economic system. Potts also argues that we need to analyse the stocks and flows of information capital, however defined, and ICT are obviously one major way the two are connected. Mirowski (2002) traces the shift from the neo-classical field definition of economics as 'the allocation of scarce resources to given ends' to the cyborg definition of the economy as a giant information processor, and outlines the extent to which economics has become a cyborg science.

What these contributions suggest to me is that economics-related ICT research is part of a bigger agenda going back to the pioneers, i.e. to find the proper place for information/knowledge in economics. The broad concept of information/knowledge 
(be it as a resource, as capital, as flows) takes us back to the beginnings of interest in the information economy, and it can be postulated that it is a broad inter-disciplinary but unified theory of information and knowledge that is needed (see, e.g., Hofkirchner, 1999), or a meta-discipline of decision and information sciences, not a narrower proto-discipline of ICT or Internet Research. However, the quest for such a meta-discipline is likely to be a long one, i.e. it is unlikely that disciplinary boundaries will diminish much in the near future, although there are always exceptions to prove the rule. One of them might be a profound change in the relationship between humans and technology, such as the scenario that sees the information-processing capacity of computers exceed the capacity of the human brain in the near future. ${ }^{11}$ In case of such a revolutionary change in human versus machine evolution, all bets regarding the organisation of knowledge would be off. 


\section{REFERENCES}

Bell, Daniel, 1973. The Coming of Postindustrial Society. New York: Basic Books.

Economist, The, 1998. Journey Beyond the Stars: The Brightest Young Economists are Outgrowing their Discipline's Traditional Boundaries. December $19^{\text {th }}, 143-146$.

Engelbrecht, Hans-Jürgen, 1988. Information Resources in U.S. Manufacturing: A Reassessment. The Information Society 5(3): 147-159.

Engelbrecht, Hans-Jürgen, 1998. A Communication Perspective on the International Information and Knowledge System. Information Economics and Policy 10(3): 359367.

Engelbrecht, Hans-Jürgen, 2003. Data Issues in the New Economy. In New Economy Handbook, ed. D. Jones. San Diego and London: Elsevier/Academic Press, 57-76.

Engelbrecht , Hans-Jürgen, 2004 (forthcoming), Review of D. Foray, The Economics of Knowledge, MIT Press , In Prometheus 22(4).

Foray, Dominique, 2004. The Economics of Knowledge. Cambridge, MA: MIT Press.

Hayes, Robert M. and Timothy Erickson, 1982. Added Value as a Function of Purchases of Information Services. The Information Society 1(4): 307-338. 
Helpman, Elhanan, ed. 1998. General Purpose Technologies and Economic Growth. Cambridge, MA: MIT Press.

Hofkirchner, Wolfgang, 1999. The Quest for a Unified Theory of Information. Amsterdam: Gordon and Breach Publishers.

Jones, Derek, ed. 2003. New Economy Handbook. San Diego and London: Elsevier/Academic Press.

Machlup, Fritz, 1962. The Production and Distribution of Knowledge in the United States. Princeton, N.Y.: Princeton University Press.

McKnight, Lee W. and Joseph P. Bailey, 1997. An introduction to Internet Economics. In Internet Economics, eds. L. W. McKnight and J. Bailey. Cambridge, MA: MIT Press, 3-24.

Mirowski, Philip, 2002. Machine Dreams: Economics Becomes a Cyborg Science. Cambridge, U.K.: Cambridge University Press.

Pohjola, Matti, ed. 2001. Information Technology, Productivity, and Economic Growth: International Evidence and Implications for Economic Development. Oxford and New York: Oxford University Press. 
Pohjola, Matti, ed. 2002. Special Issue on the New Economy. Information Economics and Policy 14(2), pp. 133-326.

Porat, Marc U. and Michael R. Rubin, 1977. The Information Economy (in 9 Volumes). Washington, D.C.: Government Printing Office.

Potts, Jason, 2000. The New Evolutionary Microeconomics: Complexity, Competence and Adaptive Behaviour. Cheltenham, U.K.: Edward Elgar.

Potts, Jason, 2003. The Prometheus School of Information Economics. Prometheus 21(4): 477-486.

Quah, Danny, 2003. Digital goods and the New Economy. In New Economy Handbook, ed. D. Jones. San Diego and London: Elsevier/Academic Press, 289-321.

Shapiro, Carl and Hal Varian, 1999. Information Rules: A Strategic Guide to the Network Economy. Boston, MA: Harvard Business School Press.

Stiglitz, Joseph E., 2002. Information and the Change in the Paradigm in Economics. American Economic Review 92(3): 460-501.

Stiroh, Kevin J., 2003. Growth and innovation in the New Economy. In New Economy Handbook, ed. D. Jones. San Diego and London: Elsevier/Academic Press, 723-751. 
${ }^{1}$ To save a lengthy discussion, the terms information and knowledge are used more or less synonymously in this paper. The relationship between the information economy and the knowledge(-based) economy is a vexed question beyond the scope of this paper.

2 This example is not meant to defend the methodological approach of using ‘information inputs' in conventional economic analysis. The topic is contested territory and beyond the scope of this paper. On ICT growth accounting, see Stiroh (2003), and the references cited therein.

${ }^{3}$ There are exceptions to this narrowing in scope, but they are outside the mainstream (see, e.g., Potts, 2003).

${ }^{4}$ The importance of ICT for economic growth not only in the US, but also in other developed and newly industrialized countries, is being documented by an increasing number of authors. The findings for developing countries are usually more mixed (see, e.g., Pohjola, 2001).

${ }^{5}$ One also realizes that relatively little of this has as yet been reflected in the programs of past Association of Internet Researchers (a.o.i.r.) conferences.

${ }^{6}$ Although he does comment that possible dimensions of the NE can "range from ecommerce, e-government, the Internet, the productivity paradox, knowledge-intensive work, social mass-mobilization, and globalization, all the way through auction proliferation, electronic payment systems, venture capital financing saturation, and business restructuring” (Quah, 2003, p. 291).

${ }^{7}$ General purpose technologies are technologies that greatly affect a wide range of sectors of an economy. See Helpman (1998) for more precise definitions of the term.

${ }^{8}$ See, for example, the introduction to Jones (2003). 
${ }^{9}$ See Engelbrecht (2004, forthcoming) for an evaluation of Foray (2004).

${ }^{10}$ However, some prominent NE analysts, like Shapiro and Varian (1999, pp. 39/40), never doubted that 'technology changes, but economic laws do not'. For a more differentiated view, see Engelbrecht (2003). Whether economic features such as increasing returns, lock-in and network effects associated with ICT will eventually replace more standard economic assumptions is, in the end, an empirical question. For the foreseeable future, ICT will transform some industries more than others.

${ }^{11}$ I thank a referee for mentioning this possibility. 
ICT Research, the New Economy, and the Evolving Discipline of Economics: Back to the Future?

\author{
Engelbrecht, Hans-Jürgen
}

2006-12-17

http://hdl.handle.net/10179/9644

22/04/2023 - Downloaded from MASSEY RESEARCH ONLINE 